\title{
A Conjugative 'Plasmid' Lacking Autonomous Replication
}

\author{
By MARILYN E. NUGENT \\ Department of Bacteriology, Royal Postgraduate Medical School, Hammersmith Hospital, \\ Du Cane Road, London W12 OHS, U.K.
}

(Received 23 January 1981; revised 16 April 1981)

\begin{abstract}
Attempts were made to isolate open and covalently closed circular DNA from strains containing the IncJ plasmids. All of the methods tried were unsuccessful. It was shown that the IncJ plasmid R391 can integrate into the Escherichia coli $\mathrm{K} 12$ chromosome and can mobilize chromosomal markers from a single origin in an orientated manner. It is proposed that the IncJ plasmids are integrated in the chromosome for most, if not all, of their existence and this explains the inability to isolate plasmid DNA from strains containing them.
\end{abstract}

\section{INTRODUCTION}

Incompatibility group $\mathrm{J}$ includes a group of plasmids detected in strains of Proteus and Providence from Pretoria (Coetzee et al., 1972; Hedges, 1974, 1975), R997 from an Indian strain of Proteus mirabilis (Matthew et al., 1979) and pJY1 from a strain of Vibrio cholerae isolated in the Phillipines (Yokata \& Kuwahara, 1977). All of the South African IncJ plasmids determined resistance to kanamycin and mercuric ions; R997 determined resistance to ampicillin, streptomycin and sulphonamides; and pJY1 determined resistance to chloramphenicol, streptomycin and sulphonamides.

Although these plasmids showed all the genetic characteristics of extrachromosomal elements, attempts to isolate covalently closed circular (CCC) DNA forms of plasmids R391, R392 and R997 by dye-buoyant density gradient ultracentrifugation were unsuccessful (Hedges et al., 1975). In the present work, four different methods were used in attempts to isolate plasmid DNA from strains carrying several members of group J. All the methods failed.

During the course of this work, the possibility was investigated that the IncJ plasmids existed in a chromosomally integrated form. Several workers have found that various plasmids can integrate stably into the bacterial chromosome and constitute Hfr strains that transfer chromosomal genes sequentially. These include F (Jacob \& Wollman, 1961; Hayes, 1968), F-like plasmids including ColB and ColV (Kahn, 1968), and the IncI $\alpha$ plasmids R483 and R 144 (Datta \& Barth, 1976). Recently, Sasakawa et al. (1980) have shown chromosome integration and $\mathrm{Hfr}$ formation by plasmids of incompatibility groups FIV, H1, H2, M and N. Although many other plasmids have also been shown to mobilize bacterial chromosomes (for review, see Holloway, 1979) there is little convincing evidence that these integrate into the chromosome. The present work demonstrates that IncJ plasmid R391 mobilizes the Escherichia coli chromosome from a single origin, and transfer of chromosomal markers occurs in an orientated manner. Integrated R391 suppresses dnaA mutants that are temperature sensitive for the initiation of chromosomal replication by using its own origin of replication. It is proposed that the IncJ 'plasmid' R391 normally exists in a chromosomally integrated form and transfer of resistance markers is concomitant with the transfer of chromosomal markers. 
Table 1. Escherichia coli K12 strains and IncJ plasmids

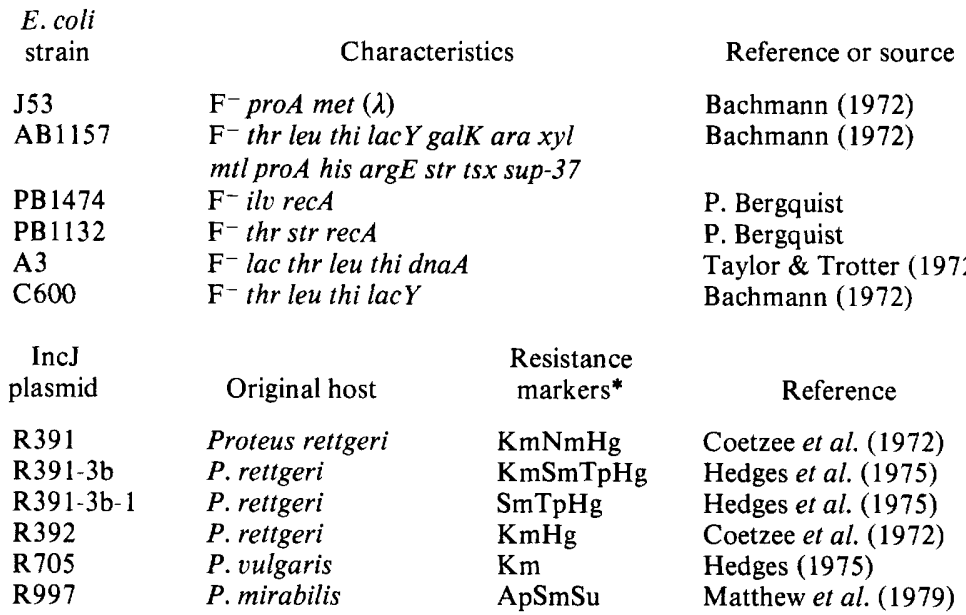

* Symbols for drug and heavy metal resistance: $\mathrm{Ap}$, ampicillin; $\mathrm{Hg}$, mercuric ions; $\mathrm{Km}$, kanamycin; $\mathrm{Nm}$, neomycin; Sm, streptomycin; Su, sulphonamide; Tp, trimethoprim.

\section{METHODS}

Bacterial strains and plasmids. The Escherichia coli $\mathrm{K} 12$ strains and plasmids used are described in Table 1.

DNA isolation. Three different methods were used: the cleared lysate method of Meyers et al. (1976); the method of Barth \& Grinter (1974); and a larger scale method using 1 litre of culture based on that of Clewell \& Helinski (1969).

Single colony lysates. Single colonies were lysed directly on $0.7 \%(\mathrm{w} / \mathrm{v})$ agarose slab gels and examined for the presence of plasmid species by electrophoresis as described by Eckhardt (1978). Standard reference plasmids used were RA1 (mol. wt $\left.86 \times 10^{6}\right)$, R $1\left(62 \times 10^{6}\right)$, R $702\left(46 \times 10^{6}\right)$ and RP4 $\left(36 \times 10^{6}\right)(\mathrm{Jacob}$ et al., 1977).

Plasmid mobilization of chromosomal markers. The donor strain J53(R391) was grown without shaking to approximately $10^{8}$ cells $\mathrm{ml}^{-1}$. The recipient strain AB1157 was grown with shaking to approximately $10^{9}$ cells $\mathrm{ml}^{-1}$. Equal volumes of donor and recipient cultures were mixed and incubated at $37^{\circ} \mathrm{C}$, without shaking, for 100 $\min$. The mating mixture was then blended in a vortex mixer and $0.1 \mathrm{ml} \mathrm{samples} \mathrm{were} \mathrm{spread} \mathrm{on} \mathrm{media} \mathrm{selective}$ for each of the markers of $\mathrm{AB} 1157$ indicated in Table 2. The frequency of transfer of kanamycin resistance to $\mathrm{AB} 1157$ was also determined. Streptomycin $\left(15 \mu \mathrm{g} \mathrm{m}^{-1}\right)$ was used to counterselect the donors. Viable counts of the donor and recipient cultures just before mating were also measured.

Test for suppression of the DnaA phenotype. Clones of strains A3 and A3(R391) were grown overnight in $10 \mathrm{ml}$ nutrient broth at $30^{\circ} \mathrm{C}$. Dilutions of these broth cultures were plated on prewarmed nutrient agar and incubated at $30^{\circ} \mathrm{C}$ and $42{ }^{\circ} \mathrm{C}$. Counts were made after $48 \mathrm{~h}$ incubation.

\section{RESULTS}

Attempted DNA isolation. Using the single colony lysate method of Eckhardt (1978) with the strains carrying the IncJ plasmids described in Table 1, no plasmid bands were seen for any of these plasmids even though the standard plasmids used were clearly visible on the gel. The method of Barth \& Grinter (1974) was used in an attempt to isolate CCC DNA of the IncJ plasmids described in Table 1. After dye-buoyant density gradient ultracentrifugation no bands of CCC DNA were seen. A similar result was obtained using a larger scale method for extracting plasmid DNA from a 1 litre culture of strain J53(R391) by a Brij lysis technique based on the method of Clewell \& Helinski (1969).

The possibility that the IncJ plasmids might be in the open circular form for most of their existence was tested using the cleared lysate method of Meyers et al. (1976), which does not involve the separation of open and closed circular DNA molecules. Any isolated plasmid DNA was examined by gel electrophoresis as described by Meyers et al. (1976). Again, no plasmid bands were seen with any of the IncJ plasmids investigated. 
Table 2. Chromosome mobilization by plasmid R391

The donor strain J53(R391) was mated with strain AB1157 for 100 min as described in Methods. Results are the mean values for six mobilization experiments. In addition to the results shown, $\mathrm{Gal}^{+}, \mathrm{His}^{+}, \mathrm{Xyl}^{+}$or $\mathrm{Arg}^{+}$colonies that were probably revertants of the recipient strain were obtained at a frequency of $10^{-8}$ per donor or less. This was due to killing of transconjugants carrying markers beyond gal by zygotic induction of $\lambda$.

$\begin{array}{cc}\text { Phenotype selected } & \text { Transfer frequency per donor* } \\ \mathrm{Km} & 0.8 \times 10^{-6} \\ \mathrm{Thr}^{+} & 0.61 \times 10^{-6} \\ \mathrm{Ara}^{+} & 0.22 \times 10^{-6 \dagger} \\ \mathrm{Leu}^{+} & 0.47 \times 10^{-6} \\ \mathrm{Lac}^{+} & 0.36 \times 10^{-7}\end{array}$

* Results have been corrected for the reversion frequency of markers.

+ This frequency is lower than would be expected considering the position of ara with respect to leu on the E. coli linkage map (Taylor \& Trotter, 1972). This may be due to some delay or defect in the expression of ara under the experimental conditions used. Lower than expected transfer frequencies for ara and other sugars have been noted by previous workers (for example, see Barth, 1979).

\section{Table 3. Growth of $A B 1157(R 391) T h r^{+}$recombinants on selective media}

The growth requirements of $100 \mathrm{Thr}^{+}$recombinants were determined by growth on selective medium. Results are expressed as the percentage of clones growing on medium without a certain marker requirement.

$\begin{array}{cc}\text { Unselected phenotype } & \text { Clones (\%) } \\ \mathrm{Thr}^{+} & 100 \\ \mathrm{Ara}^{+} & 53 \\ \mathrm{Leu}^{+} & 39 \\ \mathrm{Lac}^{+} & 7 \\ \mathrm{Gal}^{+} & 0 \\ \mathrm{His}^{+} & 0 \\ \mathrm{Xyl}^{+} & 0 \\ \mathrm{Arg}^{+} & 0 \\ \mathrm{Km}^{+} & 100 \\ \mathrm{HgCl} & 100\end{array}$

Attempted transfer of IncJ plasmids to recA strains. It was noted previously that the IncJ plasmids transfer between $\mathrm{Rec}^{+}$strains of $E$. coli $\mathrm{K} 12$ with rather low frequencies ranging from $10^{-5}$ to $10^{-6}$ per donor cell (Coetzee et al., 1972). In the present work, the ability of IncJ plasmids to transfer their resistance markers to the $E$. coli rec $A$ strains $\mathrm{PB} 1132$ and PB 1474 was investigated. In these matings no transconjugants were obtained with any of the IncJ plasmids tested.

Suppression of the DnaA phenotype by plasmid R391. Plasmid R391 was transferred to the E. coli $\mathrm{K} 12$ strain $\mathrm{A} 3$ at $30^{\circ} \mathrm{C}$. Three colonies each of $\mathrm{A} 3\left(\mathrm{R}^{-}\right)$and $\mathrm{A} 3(\mathrm{R} 391)$ were grown in nutrient broth overnight and plated as described in Methods. Colony counts for $\mathrm{A} 3\left(\mathrm{R}^{-}\right)$cultures were lower by a factor of about $10^{7}$ for those grown at $42{ }^{\circ} \mathrm{C}$ as compared with $30^{\circ} \mathrm{C}$. Colony counts for A3(R391) were only 10 -fold lower at $42{ }^{\circ} \mathrm{C}$ as compared with $30^{\circ} \mathrm{C}$. This suppression of the chromosomal DnaA phenotype indicated that R391 integrates into the chromosome and permits chromosomal replication from the R391 origin.

Mobilization of chromosomal markers by plasmid R391. The ability of R391 to mobilize various auxotrophic markers and kanamycin resistance from E. coli J53(R391) to AB1157 was tested. R391 gave a characteristic gradient of transmission of chromosomal markers (Table 2). The proximal marker transferred was kanamycin resistance. The frequency of transfer of kanamycin resistance was approximately 1.3 times that of $\mathrm{Thr}^{+}$. Similar transfer frequencies were obtained for six different clones of J53(R391) indicating a single origin of transfer. Crosses of the $\lambda$ lysogen J53(R391) with AB 1157 will give rise to zygotic induction 
of $\lambda$ and will kill transconjugants carrying chromosomal markers beyond gal. A small number of $\mathrm{His}^{+}$and $\mathrm{Arg}^{+}$colonies were obtained (Table 2); these were probably due to reversion of the recipient strain.

Examination of recombinants. One hundred colonies were selected on medium containing all the requirements of $\mathrm{AB} 1157$ apart from threonine. All were resistant to kanamycin although selection had not been applied. Close linkage was found between the thr, ara and leu auxotrophic markers (Table 3 ) as would be expected from their position on the $E$. coli linkage map (Taylor \& Trotter, 1972).

Characteristics of strain AB1157(R391). The ability of AB1157(R391) $\mathrm{Thr}^{+}$to transfer both kanamycin resistance and $\mathrm{Thr}^{+}$to $E$. coli strain $\mathrm{C} 600$ was investigated. The transfer frequencies seen for kanamycin resistance and $\mathrm{Thr}^{+}$were similar to those observed with J53(R391). It appears that $\mathrm{R} 391$ retains its ability to mobilize chromosomal markers when it has transferred itself into a different strain.

Incompatibility properties of plasmids $R 391$ and $R 391-3 b-1$. The plasmid R $391-3 \mathrm{~b}$ was derived from the transposition of transposon $7(\operatorname{Tn} 7)$, conferring trimethoprim and streptomycin resistance, into R391 (Hedges et al., 1975). Trimethoprim and kanamycin resistance are transferred at equal frequencies from strains containing R391-3b. Assuming that R391 has a chromosomal location this implies that $\mathrm{Tn} 7$ is located very close to the kanamycin resistance gene of R391. R391-3b-1 is a segregant of R391-3b that does not code for kanamycin resistance (Hedges et al., 1975); it could have arisen by a naturally occurring mutation, by a deletion induced by $\operatorname{Tn} 7$ or by insertion of $\mathrm{Tn} 7$ into the kanamycin resistance determinants.

It was noted by Hedges et al. (1975) that when R391 was transferred into a strain containing R391-3b-1 with selection for kanamycin resistance, $90 \%$ of transconjugants had lost the resident plasmid. The remaining transconjugants were 'doubles' which carried the resistance markers of both R391 and R391-3b-1. In the present work the stability of these 'doubles' was investigated. One of these was grown overnight in drug-free nutrient broth, and the culture was plated on nutrient agar to give single colonies. All of the 200 colonies tested carried the resistance markers of R391 and R391-3b-1. One of these colonies was tested further as described above, and again all of the 200 colonies tested were 'doubles'.

The transfer frequencies of kanamycin and trimethoprim resistance from these 'doubles' into the strain AB1157 was determined. Mating times and conditions were as described in Methods. Kanamycin resistance was transferred at a frequency of $10^{-5}$ per donor cell whereas the transfer frequency of trimethoprim resistance was $10^{-8}$ per donor cell.

These incompatibility properties can be explained in a way that supports the hypothesis that R391 has a chromosomal location.

\section{DIS CUSSION}

There is no evidence for the autonomous existence of the IncJ plasmids in the open or closed circular plasmid DNA forms. Several different DNA isolation methods were tried which consistently met with failure. This suggested that these plasmids are integrated in the chromosome for most if not all of their existence.

The suppression of the dnaA mutation of strain A 3 by plasmid R391 indicates that R391 is integrated into the chromosome of A3 and chromosomal replication is permitted using the $\mathrm{R} 391$ replication origin. This chromosomal location of R391 is also indicated by its ability to mobilize $E$. coli chromosomal markers. Different clones of a strain carrying R391 give a characteristic gradient of transmission, the proximal marker always being kanamycin resistance. These results indicate a single integration site of R391 on the chromosome near to $t h r$. The $\mathrm{Thr}^{+}$recombinants obtained after chromosomal mobilization into strain $\mathrm{AB} 1157$ also confer kanamycin resistance and are able to mobilize the chromosome of AB1157. R391 
therefore retains the mobilizing ability when it has been transferred to different strains of $E$. coli.

The incompatibility properties of the IncJ 'plasmids' R391 and R391-3b-1 can also be explained by proposing a chromosomal location for R391. In matings between strains carrying these two plasmids where there is selection for the incoming plasmid the resident plasmid is lost in the majority of transconjugants examined. The observed incompatibility arises because the plasmid in the donor strain undergoes a rec $A$-dependent recombination with the resident chromosome carrying R 391-3b-1 and displaces the resident plasmid from its chromosomal site. 'Doubles' of R391 and R391-3b-1 were found to be stable and no loss of either plasmid resistance markers was ever seen. It is proposed that these stable 'doubles' arise from a recombination of R391 with the same chromosomal integration site as R391-3b-1 and a transposition of $\operatorname{Tn} 7$ from R391-3b-1 to a different chromosomal site. This is indicated by the low transfer frequency of trimethoprim from the stable 'doubles'. Tn7 has a 'hotspot' for integration between $d n a A$ and ilv on the E. coli chromosome (Barth et al., 1976) and the transfer frequency of these markers is similar to that of trimethoprim resistance seen in the stable 'doubles'.

R391 transfers its resistance determinants and mobilizing ability before the chromosomal markers. This is unlike the Hfr mobilization seen with $\mathrm{F}$ where only part of $\mathrm{F}$ is transferred as a proximal marker (Jacob \& Wollman, 1961). Similarly, when the IncI $\alpha$ plasmids R483 and R144 mobilized the $E$. coli chromosome. drug resistance genes were not the leading marker (Datta \& Barth, 1976).

The IncJ plasmids may lack an important function which prevents them from being totally autonomous, such as segregation functions or a complete replication system. This could be investigated further by ligating fragments of chromosomal DNA containing R391 with fragments of other plasmids such that the R391 replication origin is functional. By choosing suitable plasmids whose replication and segregation functions are well mapped it could be determined whether R391 encodes all the information for its own replication and/or segregation.

I am grateful to Professor J. N. Coetzee and Professor Naomi Datta for helpful advice during the preparation of this manuscript.

\section{REFERENCES}

BachmanN, B. J. (1972). Pedigrees of some mutant strains of Escherichia coli. Bacteriological Reviews 36, 525-557.

BARTH, P. T. (1979). Plasmid RP4, with Escherichia coli DNA inserted in vitro, mediates chromosomal transfer. Plasmid 2, 130-136.

Barth, P. T. \& Grinter, N. J. (1974). Comparison of the DNA, molecular weight and homologies of plasmids conferring linked resistance to streptomycin and sulphonamides. Journal of Bacteriology 120, 618-630.

Barth, P. T., Datta, N., Hedges, R. W. \& GrINTER, N. J. (1976). Transposition of a deoxyribonucleic acid sequence encoding trimethoprim and streptomycin resistances from R483 to other replicons. Journal of Bacteriology 125, 800-810.

Clewell, D. \& Helinski, D. (1969). Supercoiled circular DNA-protein complex in Escherichia coli: purification and induced conversion to an open circular DNA form. Proceedings of the National Academy of Sciences of the United States of America 62, 1159-1166.
Coetzee, J. N., Datta, N. \& Hedges, R. W. (1972). $\mathrm{R}$ factors from Proteus rettgeri. Journal of General Microbiology 72, 543-552.

DATTA, N. \& BARTH, P. T. (1976). Hfr formation by I pilus-determining plasmids in Escherichia coli $\mathrm{K} 12$. Journal of Bacteriology 125, 811-817.

ECKHARDT, T. (1978). A rapid method for the identification of plasmid DNA in bacteria. Plasmid 1, 584-588.

HAYES, W. (1968). The Genetics of Bacteria and their Viruses. Oxford: Blackwell Scientific Publications.

Hedges, R. W. (1974). R factors from Providence. Journal of General Microbiology 81, 171-181.

Hedges, R. W. (1975). R factors from Proteus mirabilis and $P$. vulgaris. Journal of General Microbiology 87, 301-311.

Hedges, R. W., Jacob, A. E., Datta, N. \& Coetzee, J. N. (1975). Properties of plasmids produced by recombination between $\mathrm{R}$ factors of groups $\mathrm{J}$ and FII. Molecular and General Genetics 140. 289-302.

Holloway, B. W. (1979). Plasmids that mobilize bacterial chromosome. Plasmid 2, 1-19. 
Jacob, A. E., Shapiro, J. A., Y amamoto, L., Smith, D. I., Cohen, S. N. \& Berg, D. (1977). Plasmids studied in Escherichia coli and other enteric bacteria. In DNA Insertion Elements, Plasmids and Episomes, pp. 607-638. Edited by A. I. Bukhari, J. A. Shapiro \& S. L. Adhya. New York: Cold Spring Harbor Laboratory.

JaCOB, F. \& Wollman, E. L. (1961). Sexuality and the Genetics of Bacteria. New York: Academic Press.

KAHN, P. L. (1968). Isolation of high frequency recombining strains from Escherichia coli containing the $\mathrm{V}$ colicinogenic factor. Journal of Bacteri$\operatorname{olog} y$ 96, 205-214.

Matthew, M., Hedges, R. W. \& Smith, J. T. (1979). Types of $\beta$-lactamase determined by plasmids in gram negative bacteria. Journal of Bacteriology $\mathbf{1 3 8}$, $657-704$.
Meyers, J. A., Sanchez, D., Elwell, L. P. \& Falkow, S. (1976). Simple agarose gel electrophoretic method for the identification and characterization of plasmid DNA. Journal of Bacteriology 127, 1529-1537.

Sasakawa, C., Takamatsu, N., Danbara, H. \& YoshIKAWA, M. (1980). A method of classification by integrative incompatibility. Plasmid 3, 116-127.

TAYLOR, A. L. \& TROTTER, C. D. (1972). Linkage map of Escherichia coli strain K12. Bacteriological Reviews 36, 504-524.

Yokata, T. \& Kuwahara, S. (1977). Temperaturesensitive $\mathbf{R}$ plasmid obtained from naturally isolated drug-resistant Vibrio cholerae (biotype El Tor). Antimicrobial Agents and Chemotherapy 11, 13-20. 